\title{
Variation in protein levels obtained from human blood cells and biofluids for platelet, peripheral blood mononuclear cell, plasma, urine and saliva proteomics
}

\author{
L. Katie Crosley · Susan J. Duthie - Abigael C. Polley · Freek G. Bouwman • \\ Carolin Heim · Francis Mulholland · Graham Horgan · Ian T. Johnson • \\ Edwin C. Mariman · Ruan M. Elliott · Hannelore Daniel · Baukje de Roos
}

Received: 16 February 2009/Accepted: 14 April 2009/Published online: 29 April 2009

(C) Springer-Verlag 2009

\begin{abstract}
Blood cells and biofluid proteomics are emerging as a valuable tool to assess effects of interventions on health and disease. This study is aimed to assess the amount and variability of proteins from platelets, peripheral blood mononuclear cells (PBMC), plasma, urine and saliva from ten healthy volunteers for proteomics analysis, and whether protein yield is affected by prolonged fasting. Volunteers provided blood, saliva and morning urine samples once a week for 4 weeks after an overnight fast. Volunteers were fasted for a further $24 \mathrm{~h}$ after the fourth sampling before providing their final samples. Each $10 \mathrm{~mL}$ whole blood provided $400-1,500 \mu \mathrm{g}$ protein from platelets, and 100$600 \mu \mathrm{g}$ from PBMC. $30 \mu \mathrm{L}$ plasma depleted of albumin and IgG provided $350-650 \mu \mathrm{g}$ protein. A sample of morning urine provided $0.9-8.6 \mathrm{mg}$ protein/dL, and a sample of saliva provided $70-950 \mu \mathrm{g}$ protein $/ \mathrm{mL}$. None of these yields were influenced by the degree of fasting (overnight or $36 \mathrm{~h}$ ). In conclusion, in contrast to the yields from plasma, platelets and PBMC, the protein yields of urine and saliva samples
\end{abstract}

L. K. Crosley · S. J. Duthie · B. de Roos ( $₫)$

Rowett Institute of Nutrition and Health,

University of Aberdeen, Greenburn Road,

Bucksburn, Aberdeen AB51 7HJ, UK

e-mail: b.deroos@rowett.ac.uk

\author{
A. C. Polley · F. Mulholland - I. T. Johnson - R. M. Elliott \\ Institute of Food Research, Norwich, UK \\ F. G. Bouwman · E. C. Mariman \\ Maastricht University, Maastricht, The Netherlands \\ C. Heim $\cdot$ H. Daniel \\ Technical University of Munich, Freising-Weihenstephan, \\ Germany \\ G. Horgan \\ Biomathematics and Statistics Scotland, Aberdeen, UK
}

were highly variable within and between subjects. Certain disease conditions may cause higher or lower PBMC counts and thus protein yields, or increased urinary protein levels.

Keywords PBMC - Plasma - Platelets - Protein levels · Proteomics $\cdot$ Saliva $\cdot$ Urine

$\begin{array}{ll}\text { Abbreviations } \\ \text { 2D } & \text { Two-dimensional } \\ \text { ANOVA } & \text { Analysis of variance } \\ \text { BMI } & \text { Body mass index } \\ \text { BSA } & \text { Bovine serum albumin } \\ \text { CHAPS } & \text { 3-[(3-Cholamidoprophyl)dimethyl- } \\ & \text { ammonium]-1-propanesulfonate } \\ \text { CV } & \text { Coefficient of variation } \\ \text { DTT } & \text { Dithiothreitol } \\ \text { EDTA } & \text { Ethylenediaminetetraacetic acid } \\ \text { HIV } & \text { Human immunodeficiency virus } \\ \text { IgG } & \text { Immunoglobulin G } \\ \text { kDa } & \text { kilo Dalton } \\ \text { PBMC } & \text { Peripheral blood mononuclear cells } \\ \text { PRP } & \text { Platelet rich plasma } \\ \text { SD } & \text { Standard deviation } \\ \text { TCA } & \text { Trichloroacetic acid } \\ \text { Tris } & \text { Tris(hydroxymethyl)aminomethane }\end{array}$

Introduction

Proteomics is emerging as a valuable tool in nutritional and clinical research $[6,8,13,21,23,24,27]$. Proteome analysis from easily-accessible human body fluids and blood cells can identify thousands of proteins, which may 
provide valuable new biomarkers for health and disease progression and enable discovery of mechanisms of action of food components [24]. Indeed, fish oil supplementation in healthy volunteers changed levels of structural and antiinflammatory platelet proteins (B. de Roos, unpublished results) and serum biomarkers of inflammation and lipid modulation [7]. Healthy males ingesting flaxseed [11], and postmenopausal women supplemented with isoflavone extract [12] showed changes in PBMC proteins involved in oxidative stress, inflammation, fatty acid oxidation and glycolysis [11, 12]. Moreover, platelet and PBMC proteomics represented a more sensitive method for detecting modulation of inflammatory processes compared with plasma markers that are classically used (B. de Roos, unpublished results) [12].

Proteomic profiling of blood and blood cells, however, is still in need of further refinement [4]. The technique is potentially liable to large within- and between-subject background variation because of rapid changes in response to external signals, differences in methods of blood sampling and sample preparation, and a relatively high level of technical variation inherent in the use of for example 2D gel electrophoresis technology [6]. These sources of variation can obscure the biological changes under investigation. Recently, we and others determined optimal methods to deplete human plasma of its most abundant proteins using immuno-affinity columns, concentrate protein homogenates, and isolate PBMC with minimal platelet contamination $[6,9,20,29,31]$. Here we present data on the amount and the variability of proteins available from platelets, PBMC, plasma, urine and saliva from healthy volunteers for proteomics analysis after overnight or $36 \mathrm{~h}$ fasting. This information is essential for informing the design and defining the expected scale of protein changes in human studies using proteomics.

\section{Materials and methods}

Ethical permission for the study was obtained from the North of Scotland Research Ethics Services prior to the start of the study, and all volunteers gave informed consent. Ten volunteers ( 3 males and 7 females) between the ages of 18 and 65 were recruited from the Aberdeen area. They were ascertained as healthy by a general medical examination including an haemotinic assessment, and volunteers were only included if they were not taking aspirin or aspirin-containing drugs, other anti-inflammatory drugs, or any drugs or herbal medicines known to alter platelet function or the haemostatic system in general. Table 1 provides a summary of baseline characteristics, including haemotinic results obtained during the screening for each of the volunteers.
Table 1 Baseline characteristics, including haematological analysis of blood samples obtained during screening of ten healthy volunteers (mean $\pm \mathrm{SD}$ )

\begin{tabular}{lc}
\hline Baseline characteristics & Mean $\pm \mathrm{SD}$ \\
\hline Age & $33 \pm 8$ \\
BMI & $27 \pm 7$ \\
Platelet count $\left(\times 10^{3} / \mu \mathrm{L}\right)$ & $280 \pm 62$ \\
White blood cell count $\left(\times 10^{3} / \mu \mathrm{L}\right)$ & $6.2 \pm 0.9$ \\
Lymphocyte count $\left(\times 10^{3} / \mu \mathrm{L}\right)$ & $2.1 \pm 0.6$ \\
Neutrophil count $\left(\times 10^{3} / \mu \mathrm{L}\right)$ & $3.6 \pm 0.7$ \\
Mixed cells $\left(\times 10^{3} / \mu \mathrm{L}\right)$ & $0.4 \pm 0.1$ \\
Lymphocyte $(\%$ of white blood cells $)$ & $34.3 \pm 7.8$ \\
Neutrophil $(\%$ of white blood cells $)$ & $58.3 \pm 7.9$ \\
Mixed cells $(\%$ of white blood cells $)$ & $7.3 \pm 1.5$ \\
Red blood cell count $\left(\times 10^{6} / \mu \mathrm{L}\right)$ & $4.41 \pm 0.22$ \\
Hemoglobin $(\mathrm{g} / \mathrm{dL})$ & $13.7 \pm 1.0$ \\
Hematocrit $(\%)$ & $37.8 \pm 1.7$ \\
\hline
\end{tabular}

Intervention study

During the intervention, volunteers were asked to provide once weekly for 4 weeks on different days a blood sample of $80 \mathrm{~mL}$ (for the isolation of platelets, PBMC and plasma), a saliva sample of $3 \mathrm{~mL}$, and a (second) morning urine sample. Samples were obtained after an overnight fast ( $\sim 10-12 \mathrm{~h})$. After the sample was taken in the fourth week, the volunteers were fasted for a further $24 \mathrm{~h}$ before providing their final blood, saliva and (second) morning urine sample. For the blood sampling, $30 \mathrm{~mL}$ was obtained into a closed monovette system containing trisodium citrate anticoagulant for the isolation of platelets. These monovette system tubes were kept at $37^{\circ} \mathrm{C}$ for a maximum of $30 \mathrm{~min}$ before platelet isolation. An average $( \pm \mathrm{SD})$ of $28.8 \pm 1.2 \mathrm{~mL}$ of blood was obtained into vacutainers containing potassium EDTA anticoagulant for the isolation of PBMC. These samples were kept on ice until the isolation of PBMC. Approximately $15 \mathrm{~mL}$ of blood was collected into lithium heparin vacutainers for the isolation of plasma. Haemotinic data, as well as cell counts for whole blood, platelets and PBMC, were sampled from vacutainers containing EDTA coagulant using a Sysmex KX-21N Haematology Analyser.

Isolation of platelets, PBMC, plasma, saliva and urine

Platelets were obtained from blood collected in Monovette system tubes with trisodium citrate as anticoagulant, and PBMC were isolated using the OptiPrep ${ }^{\mathrm{TM}}$ method, as described by us previously [6]. Plasma was centrifuged at $2,200 \mathrm{~g}$ for $15 \mathrm{~min}$ at $4^{\circ} \mathrm{C}$. $0.5 \mathrm{~mL}$ aliquots were removed to microtubes before being snap frozen and stored at $-80^{\circ} \mathrm{C}$ 
until required. The plasma samples were depleted of albumin and $\mathrm{IgG}$ using a kit (GE Healthcare UK Ltd, Little Chalfont, Buckinghamshire, UK). For each sample, 2 aliquots of $15 \mu \mathrm{L}$ each were processed in parallel according to the manufacturer's instructions. The two filtrates obtained for each sample were pooled and concentrated to approximately $100 \mu \mathrm{L}$ by centrifugation at $12,000 \mathrm{~g}$ at $10^{\circ} \mathrm{C}$ in a centrifugal ultrafiltration device with a nominal molecular weight limit of $5 \mathrm{kDa}$ (Millipore Ultrafree-0.5, Millipore (UK) Ltd, Watford, Hertfordshire, UK) that had been prewashed with ultrapure water according to the manufacturer's instructions. Each sample concentrate was mixed with $200 \mu \mathrm{L}$ of rehydration buffer (7 M urea, $2 \mathrm{M}$ thiourea, $2 \% \mathrm{w} / \mathrm{v}$ CHAPS) and the samples centrifuged in the same ultrafiltration units at $12,000 \mathrm{~g}$ at $19^{\circ} \mathrm{C}$ to concentrate each to approximately $80 \mu \mathrm{L}$. The samples were transferred to microfuge tubes, and the filter washed twice with $20 \mu \mathrm{L}$ of rehydration buffer before the washes were combined with the appropriate sample. The final sample volume was recorded prior to storage at $-80^{\circ} \mathrm{C} .3 \mathrm{~mL}$ of saliva was collected by spitting into a $50 \mathrm{~mL}$ tube after rinsing the mouth twice with water. $3 \mu \mathrm{L}$ Complete (Roche, 1 tablet in $10 \mathrm{~mL} 18.2 \mathrm{M} \Omega \mathrm{cm}$ water) was added immediately to the saliva and the sample centrifuged at $16,245 \mathrm{~g}$ for $15 \mathrm{~min}$ at $4^{\circ} \mathrm{C}$. $1 \mathrm{~mL}$ aliquots of supernatant were removed to fresh microtubes and snap frozen prior to storage at $-80^{\circ} \mathrm{C}$ for protein analysis. The morning urine was collected to a $2 \mathrm{~L}$ bottle, and $3 \mathrm{M}$ sodium azide was added instantly. The sample was centrifuged at $750 \mathrm{~g}$ for $8 \mathrm{~min}$ at $4^{\circ} \mathrm{C}$. The supernatant was transferred to a fresh tube and stored at $-80^{\circ}$ for protein analysis.

Protein analysis

Platelet and PBMC proteins were extracted into buffer containing $7 \mathrm{M}$ Urea, $2 \mathrm{M}$ Thiourea, 2\% CHAPS and $0.06 \%$ proteinase inhibitor cocktail (Roche) as described by us previously [6]. To isolate proteins from saliva, $900 \mu \mathrm{L}$ of ice-cold acetone containing $10 \%$ TCA and $20 \mathrm{mM}$ DTT was added to $300 \mu \mathrm{L}$ saliva and incubated overnight at $-20^{\circ} \mathrm{C}$. After centrifugation at $20,000 \mathrm{~g}$ for $15 \mathrm{~min}$ at $4^{\circ} \mathrm{C}$, a pellet was obtained and washed with icecold acetone, which was centrifuged again at 20,000 $\mathrm{g}$ for 5 min at $4^{\circ} \mathrm{C}$, after which the dry pellet was obtained. The pellet was dissolved in $100 \mu \mathrm{L}$ rehydration buffer containing $7 \mathrm{M}$ urea, $2 \mathrm{M}$ thiourea, 2\% CHAPS, $65 \mathrm{mM}$ DTT and $0.5 \%$ 3-10 non-linear IPG buffer (GE Healthcare) during $30 \mathrm{~min}$ at room temperature. To isolate proteins from urine, $40 \mathrm{~mL}$ urine was precipitated with $160 \mathrm{~mL}$ acetone and incubated at $-20^{\circ} \mathrm{C}$ for $1 \mathrm{~h}$, after which the sample was centrifuged at $12,000 \mathrm{~g}$ at $4^{\circ} \mathrm{C}$ for $20 \mathrm{~min}$. After air-drying, the pellet was resuspended in lysis buffer containing $7 \mathrm{M}$ urea, $2 \mathrm{M}$ thiourea, 4\% CHAPS, $120 \mathrm{mM}$
DTT, $40 \mathrm{mM}$ Tris and proteinase inhibitor. The solution was sonicated (20 strokes, amplitude 35 , interval 0.5 ) to solubilise proteins, and dialysed with an $8 \mathrm{kDa}$ cut-off mini dialysis kit against water at $4{ }^{\circ} \mathrm{C}$ overnight. A second acetone precipitation step was performed and proteins were solubilised by sonication as described above. Protein concentrations of platelets, PBMC, saliva and urine were assessed by the RC/DC assay (BioRad) according to the manufacturer's instructions. The protein contents of complete plasma samples and albumin/IgG depleted plasma samples were determined using 2-D Quant kits (GE Healthcare UK Ltd, Little Chalfont, Buckinghamshire, UK) according to the manufacturer's instructions.

\section{Statistical analysis}

For each variable ANOVA, with a blocking term for volunteer and samples as a treatment term, was used to assess whether values following prolonged fasting were significantly different from baseline values. A contrast between the four baseline samples and the one fasting sample was included in each ANOVA. Whether outcomes were dependent on age and body mass index (BMI) was investigated by including these as covariates in the betweensubject stratum of the analysis. Statistical analyses were performed in Genstat version 10 (VSN International Ltd, UK).

\section{Results}

Haemotinic results during the 4 weeks sampling period (at the four baseline samplings and after the $36 \mathrm{~h}$ fasting challenge) did not differ from the screening results that are summarised in Table 1 (data not shown).

\section{Platelets}

Whole blood platelet counts in the four baseline samples from each subject ranged from 178 to $409 \times 10^{6} / \mathrm{mL}$ whole blood with an intra-individual coefficient of variation $(\mathrm{CV})$ ranging from 2 to $18 \%$ and an inter-individual CV of $20-22 \%$ (Fig. 1a). In the baseline samples, the number of platelets in PRP isolated per $\mathrm{mL}$ whole blood ranged from 8.9 to $21 \times 10^{6}$, with an intra-individual $\mathrm{CV}$ of $1-10 \%$ and an inter-individual $\mathrm{CV}$ of $18-22 \%$ between baselines (Fig. 1b). Whole blood and PRP platelet counts were not significantly different between baseline samples (taken after an overnight fast) and the sample taken after the prolonged $36 \mathrm{~h}$ fasting challenge, and were not dependent on age or BMI, as assessed by ANOVA. Figure 1c shows the relationship between the amount of platelets isolated from 3 Monovette system $10 \mathrm{~mL}$ tubes 

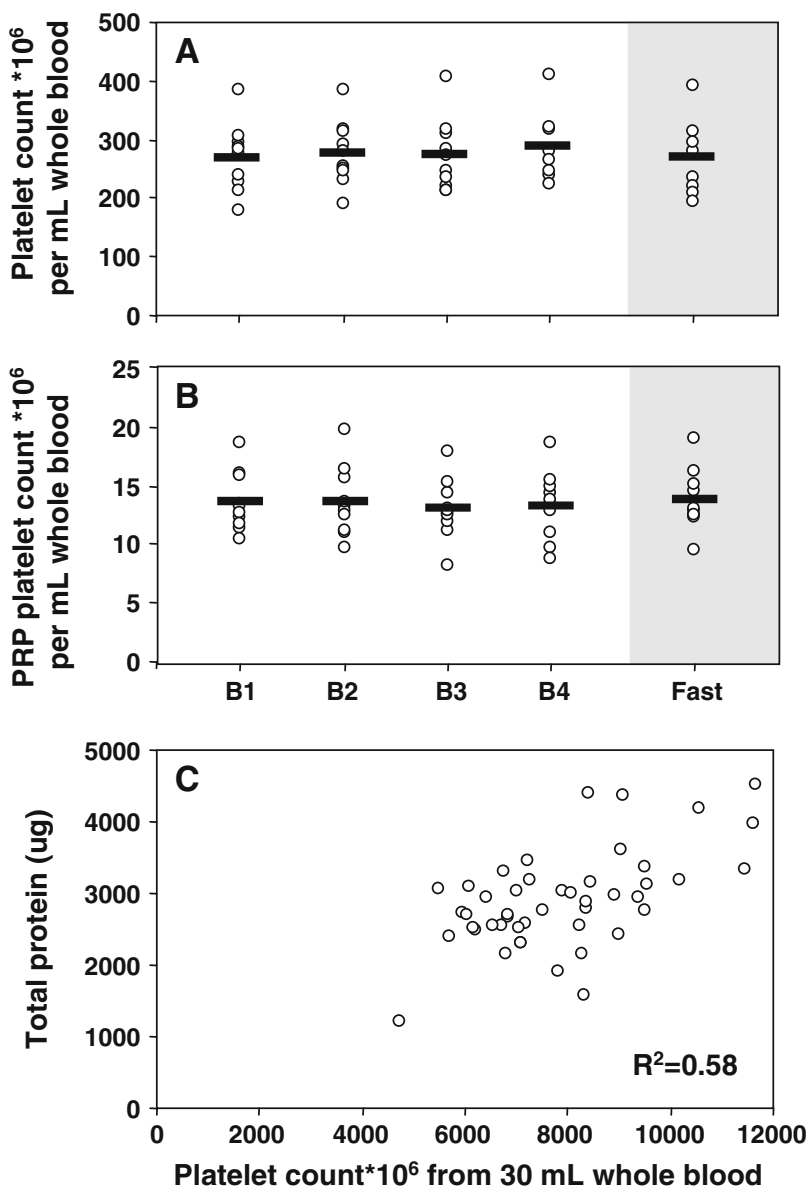

Fig. 1 Individual (open circle) and mean (thick dash) platelet counts $\left(\times 10^{6}\right)$ per $\mathrm{mL}$ of whole blood (a), or platelet rich plasma platelet count $\left(\times 10^{6}\right)$ originating from a mL whole blood (b) during four baseline samplings (B1, B2, B3 and B4) and after a fasting challenge (Fast). c Correlation between platelet count $\left(\times 10^{6}\right)$ from $30 \mathrm{~mL}$ whole blood with total protein yield

$(30 \mathrm{~mL})$ and the amount of protein extracted from the subsequent platelet pellet. From $30 \mathrm{~mL}$ of whole blood it was possible to extract between 1,200 and $4,517 \mu \mathrm{g}$ of platelet proteins, with an intra-individual $\mathrm{CV}$ ranging from 6 to $38 \%$ and an inter-individual $\mathrm{CV}$ of $20-26 \%$ between baselines.

\section{PBMC}

Whole blood PBMC counts in the four baseline samples from each subject ranged from 1.1 to $3.7 \times 10^{6} / \mathrm{mL}$ with an intra-individual CV ranging from 4 to $16 \%$ and an interindividual $\mathrm{CV}$ ranging from 25 to $32 \%$ (Fig. 2a). In the baseline samples, the number of PBMC obtained from three $10 \mathrm{~mL}$ and one $5 \mathrm{~mL}$ vacutainers $(\sim 29 \mathrm{~mL})$ whole blood ranged from 11.3 to $50 \times 10^{6}$, with an intra-individual $\mathrm{CV}$ of $4-30 \%$ and an inter-individual $\mathrm{CV}$ of 26-47\% between baselines (Fig. 2b). PBMC counts were
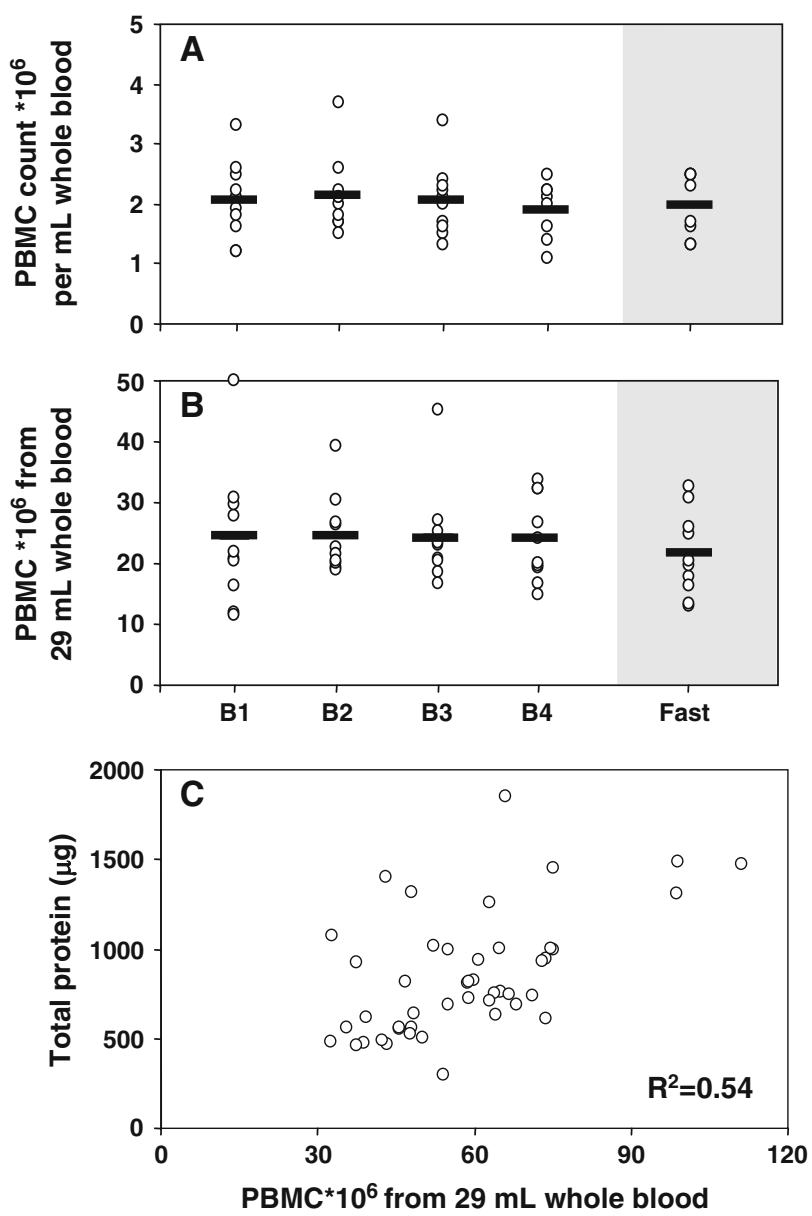

Fig. 2 Individual (open circle) and mean (thick dash) PBMC counts $\left(\times 10^{6}\right)$ per $\mathrm{mL}$ whole blood $(\mathbf{a})$, or PBMC count $\left(\times 10^{6}\right)$ originating from $29 \mathrm{~mL}$ whole blood (b) during four baseline samplings (B1, B2, B3 and B4) and after a fasting challenge (Fast). c Indicates correlation between platelet count $\left(\times 10^{6}\right)$ from $29 \mathrm{~mL}$ of whole blood with total protein yield

not significantly different between baseline samples (taken after an overnight fast) and the sample taken after the prolonged $36 \mathrm{~h}$ fasting challenge, and were not dependent on age or BMI, as assessed by ANOVA. Figure 2c shows the relationship between the amount of PBMC isolated from $29 \mathrm{~mL}$ whole blood and the amount of protein extracted from the subsequent PBMC pellet. From $29 \mathrm{~mL}$ whole blood it was possible to extract between 296 and $1,849 \mu \mathrm{g}$ of PBMC proteins, with an intra-individual $\mathrm{CV}$ ranging from 9 to $41 \%$ and an inter-individual $\mathrm{CV}$ of 30 $48 \%$ between baselines. The contamination ratio of PBMC with platelets remained below 1:15 for 49 out of the 50 samples. One sample had a contamination ratio of 1:24.

\section{Plasma}

The amount of protein extracted from plasma during baseline from each subject ranged from 53.9 to $78.2 \mu \mathrm{g} / \mu \mathrm{L}$ 
(Fig. 3a). The intra-individual $\mathrm{CV}$ in baseline plasma protein yields ranged from 3 to $14 \%$ and the inter-individual $\mathrm{CV}$ ranged from 6 to $12 \%$. The degree of fasting had no significant effect on plasma protein yield, and the yield was not dependent on age or BMI, as measured by ANOVA.

After depletion of the plasma samples from albumin and $\mathrm{IgG}$ (which on average removed $79 \%$ of all proteins), the amount of protein extracted from $30 \mu \mathrm{L}$ depleted baseline sample ranged from 2.3 to $5.0 \mu \mathrm{g} / \mu \mathrm{L}$, or $339-645 \mu \mathrm{g}$ (Fig. 3b). The intra-individual $\mathrm{CV}$ in baseline depleted plasma protein yield ranged from 2 to $18 \%$, and the interindividual CV ranged from 12 to $20 \%$. The degree of fasting had no significant effect on depleted plasma protein yield, and the yield was not dependent on age or BMI, as measured by ANOVA.

\section{Urine}

The amount of collected morning urine samples from each subject ranged from 21 to $465 \mathrm{~g}$. The amount of protein extracted from morning urine baseline samples ranged from 0.9 to $8.6 \mathrm{mg} / \mathrm{dL}$ (Fig. $4 \mathrm{a}$ ). The intra-individual CV in baseline morning urine samples ranged from 7 to $93 \%$ and the inter-individual CV ranged from 52 to $84 \%$. The degree of fasting had no significant effect on morning urine
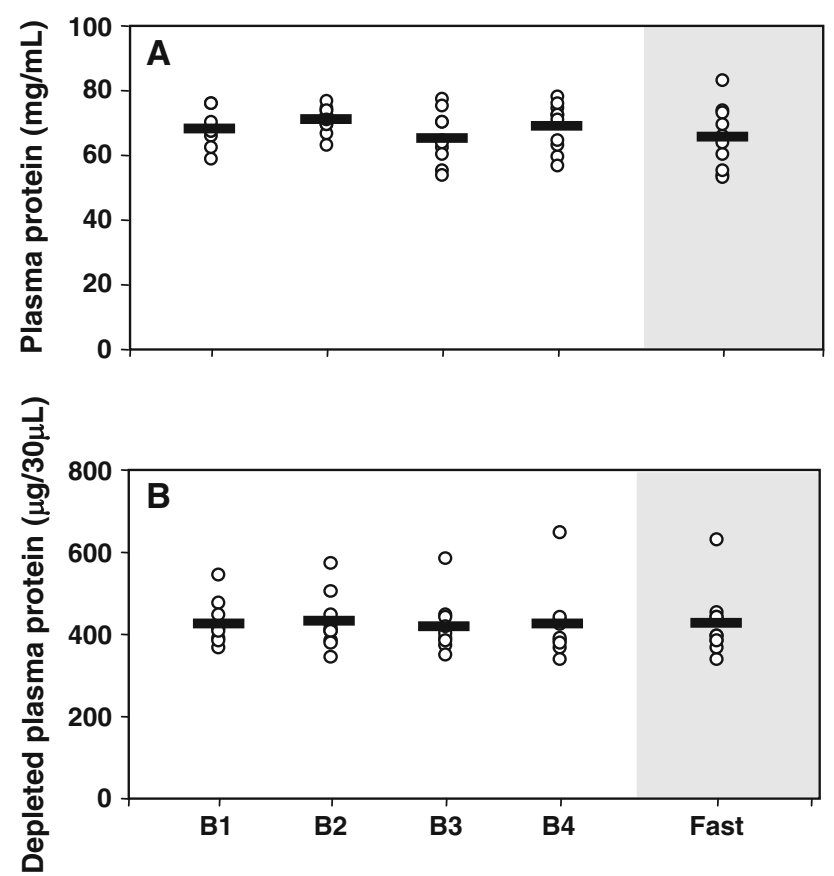

Fig. 3 Individual (open circle) and mean (thick dash) protein concentration in plasma (a), or protein yield originating from $30 \mu \mathrm{L}$ of depleted plasma (b) during four baseline samplings (B1, B2, B3 and B4) and after a fasting challenge (Fast)
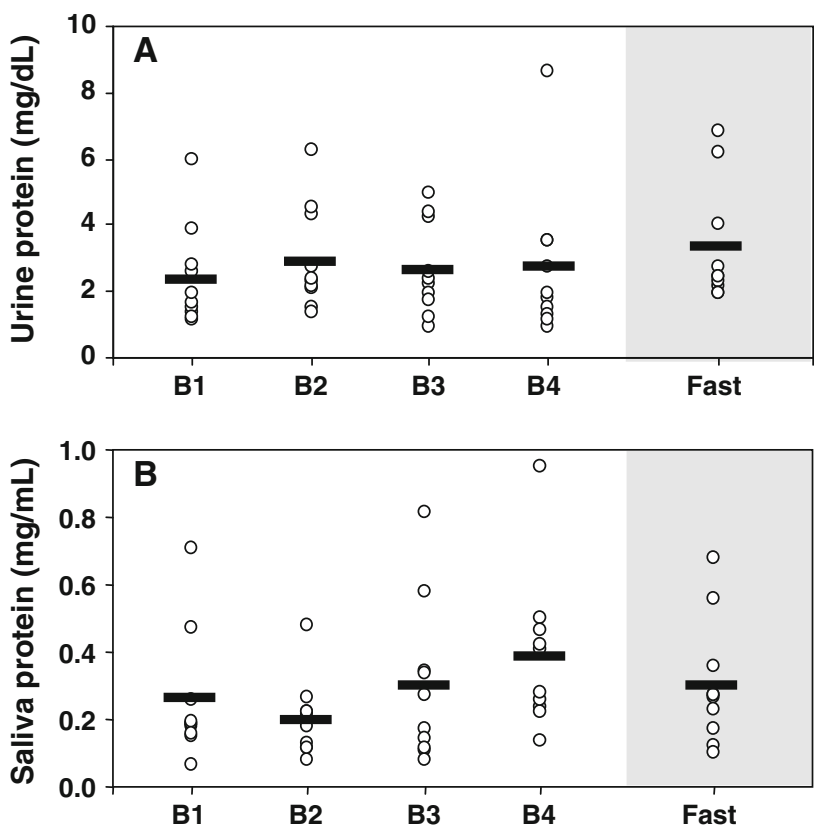

Fig. 4 Individual (open circle) and mean (thick dash) protein concentration in urine (a), or saliva (b) during four baseline samplings (B1, B2, B3 and B4) and after a fasting challenge (Fast)

protein yield, and yield was not dependent on age or BMI, as measured by ANOVA.

Saliva

The amount of protein extracted from saliva during baseline from each subject ranged from 0.07 to $0.95 \mathrm{mg}$ protein per $\mathrm{mL}$ saliva (Fig. 4b). The intra-individual CV in baseline saliva protein yields ranged from 14 to $123 \%$ and the inter-individual CV ranged from 56 to $80 \%$. The degree of fasting had no significant effect on protein yield, and yield was not dependent on age or BMI, as measured by ANOVA.

\section{Discussion}

Here we present data on the magnitude and the variability of proteins available from platelets, PBMC, plasma, urine and saliva from healthy volunteers that can be used for proteomics analysis. Each $10 \mathrm{~mL}$ of whole blood provided between 400 and $1,500 \mu \mathrm{g}$ protein from platelets after isolation and washing of these isolated cells, and between 100 and $600 \mu \mathrm{g}$ protein from PBMC proteins using the OptiPrep $^{\mathrm{TM}}$ method for PBMC isolation to minimise contamination with platelets (Fig. 1, 2). From $30 \mu \mathrm{L}$ plasma, it was possible to obtain between 350 to $650 \mu \mathrm{g}$ protein depleted of albumin and IgG using the Amersham Albumin and IgG depletion kit (Fig. 3). A spot sample of morning 
urine provided between 0.9 and $8.6 \mathrm{mg} / \mathrm{dL}$, and a spot sample of saliva provided between 70 and $950 \mu \mathrm{g}$ protein per $\mathrm{mL}$ (Fig. 4). None of these yields were influenced by the degree of fasting (i.e. overnight or a $36 \mathrm{~h}$ fasting challenge), or by the age and BMI range of the volunteers in our study.

Intra- and inter-individual variability in platelet and PBMC counts, and in protein yields from platelets, PBMC and plasma, were substantially lower compared with the variability in protein yields from saliva and urine. The proteome of whole saliva is highly susceptible to a variety of physiological and biochemical stimuli and is under neurologic control [17]. In addition, host- and bacteriaderived enzymes lead to extensive proteolytic cleavage, partial deglycosylation, and protein-protein complex formation in the mouth upon secretion of salivary proteins. Thus continuous secretion of synthesised protein products from multiple salivary glands and removal of protein products by swallowing create a dynamic and highly variable environment $[17,18]$. Despite problems with variability, projects such as the human salivary proteome project [19] will allow examination and comparison of salivary proteomes of high impact diseases such as cancers, diabetes and autoimmune diseases [18]. High intra- and inter-individual variability is also one of the problems of urine proteome analysis [33]. Urinary proteins originate from different sites, e.g. from plasma via glomerular filtration, from renal tubular epithelial cells, from shedding of whole cells or membrane fragments along the tubulus and bladder or from exosome secretion [30, 34]. According to recent recommendations for urinary proteomics [33], we collected second morning urine samples and added sodium azide instantly to minimise contamination of proteins from bacteria [3], which can change the urinary proteome profile [33]. We also removed cells and debris by centrifugation, and removed salts from urine samples by dialysis against water [33]. We did not take water loading into consideration, but protein yields were in a similar range (2-16 $\mathrm{mg} / \mathrm{mL}$ ) as reported previously [33]. The first morning urine sample provides the greatest amount of recovered proteins when equal volumes of urine are used, but shows the smallest number of visualised protein spots in $2 \mathrm{D}$ gels [35]. The establishment of standard protocols and guidelines for urine proteome analysis has been identified as an important and immediate goal of the Human Kidney and Urine Proteome Project (HKUPP) [36].

We, recently, published methodological recommendations for proteomic studies involving human plasma, platelets, and peripheral blood mononuclear cells. One recommendation was the application of single-use immunoaffinity columns, such as the Amersham albumin and $\operatorname{IgG}$ removal kit, to deplete the plasma samples of its two most abundant proteins [6]. Sample load capacity of 2D gels is severely limited by the presence of highly abundant proteins, which can mask the presence of low-abundance proteins. Depletion enables 10- to 20-fold higher amounts of serum or plasma samples to be applied to 2D gels, resulting in greater resolution of less abundant but potentially important proteins [9]. The Amersham columns were used in the current study because of efficient sample preparation time and consistent depletion of plasma samples [6]. Indeed, immuno-affinity is increasingly being accepted as the most effective sample preparation process for plasma proteomics studies, having the advantages of high specificity for target proteins, low cross-reactivity to non-target proteins, minimal disruption of the native condition of the samples, simple procedure and reproducible results, and high capacity. Multiple affinity methods are now available, some of them enabling depletion of a large range of high abundant plasma proteins [10]. A second methodological recommendation that was applied in the current human study was the use of OptiPrep ${ }^{\mathrm{TM}}$ for optimal recovery of PBMC with the lowest amount of platelet contamination [6]. Various methods exist for the isolation of PBMC from whole blood. However, a significant problem with each of these methods is contamination of PBMC with platelets, which obviously impairs the usefulness and validity of PBMC proteomics data. Lower platelet contamination, however, will result in a lower protein yield [6]. According to our previous recommendations [6], our current approach aimed towards isolation of a very pure platelet preparation while minimising platelet activation. Platelets were isolated immediately after blood donation to avoid changes in their physiological state and viability. Only the upper third of the platelet rich plasma was isolated to avoid contamination from other blood cells such as erythrocytes, leukocytes and plasma proteins [15, 28]. Platelets also underwent additional centrifugation steps to minimise potential contamination with plasma proteins normally present in platelet rich plasma, which could influence the outcome of the experiment [14]. In the current study, platelets were obtained in large quantities ( 0.5 up to $\left.1.2 \times 10^{10}\right)$ from relatively small amounts of blood $(30 \mathrm{~mL})$ (Fig. 1a), yielding from 1.2 up to $4.5 \mathrm{mg}$ of protein. This is slightly higher than found by us previously from a single blood platelet sample [6], but similar to reported by Garcia et al. [14], who found that, in general, $100 \mathrm{~mL}$ of blood yielded on average $2 \times 10^{10}$ platelets, and between 16 and $24 \mathrm{mg}$ of platelet protein.

In this study, healthy subjects with no pre-existing history of disease were recruited and haematinic markers for the group fell within normal ranges. However, certain disease states influence cell count and thus protein yield. Platelet counts are relatively stable within subjects and a low (less than $150 \times 10^{3} / \mu \mathrm{L}$ ) or high platelet count (over $450 \times 10^{3} / \mu \mathrm{L}$ ) not necessarily implies any form of disease. Occasionally, thrombocytopenia (or very low 
platelet count) may occur in some hereditary syndromes or, for example, leukaemia, liver failure and sepsis. Thrombocytosis (or high platelet count) may occur due to essential thrombocythemia or other myeloproliferative disorders [26]. Lymphocyte numbers are, however, profoundly influenced by disease. A temporary elevated lymphocyte count is often observed with acute infection, while persistent lymphocytosis is associated with chronic inflammatory-mediated pathologies such as cardiovascular disease, cancer and the metabolic syndrome [2, 32]. Absolute lymphocyte count is both a diagnostic and prognostic indicator for acute and chronic lymphocytic leukaemia [5]. A decreased circulating lymphocyte number (lymphopenia) is frequently associated with viral infections (including the common cold, influenza, hepatitis and HIV) [25], stress-related corticosteroid responses, autoimmune diseases (such as systemic lupus erythematosus and rheumatoid arthritis), certain cancers [22] and malnutrition [37]. Disease conditions can also affect urinary protein levels, as is the case in proteinuria and/or albuminuria, in which urine contains abnormally high amounts of proteins and in particularly albumin. An increased urinary albumin excretion (in the absence of other renal diseases) is found in diabetic nephropathy, the leading cause of kidney disease that affects approximately $40 \%$ of type 1 and type 2 diabetic patients, and for which hyperglycemia, increased blood pressure, and genetic predisposition are the main risk factors [16]. Albuminuria is a powerful predictor of renal and cardiovascular risk in patients with type 2 diabetes and hypertension [1]. Clearly, cell counts or protein levels in these disease states will significantly influence protein yield obtained from cells or biofluids.

In conclusion, this study provides important data on the amounts and variability of proteins available from platelets, PBMC, plasma, urine and saliva from healthy volunteers for subsequent proteomics analysis. Such information is often required for ethics applications to justify the amount of sample required from human subjects. In general, protein yields obtained from urine and saliva were highly variable within and between subjects, whereas protein yields obtained from platelets, PBMC and plasma were more constant in healthy subjects. Prolonged fasting for $36 \mathrm{~h}$ did not influence protein yields from blood cells or biofluids, although changes in protein expression are very likely after such a metabolic challenge. But certain disease conditions may cause alterations of PBMC counts and thus protein levels, or changes in the protein state of the body fluids. Thus the potential effect of infections, disease states and pathologies on blood cell numbers and biofluid protein levels in human subjects, and the subsequent employment of them for proteomics studies, must be accounted for.
Acknowledgments We acknowledge NuGO (The European Nutrigenomics Organisation: CT-2004-505944) for funding this work, and Karen Ross and Lynn Pirie for the sample preparation work. The Rowett Institute of Nutrition and Health is funded by the Scottish Government Rural and Environment Research and Analysis Directorate (RERAD). The Institute of Food Research is funded by the Biotechnology and Biological Sciences Research Council (BBSRC).

\section{References}

1. Basi S, Fesler P et al (2008) Microalbuminuria in type 2 diabetes and hypertension: a marker, treatment target, or innocent bystander? Diabetes Care 31(Suppl 2):S194-S201

2. Bell DS, O'Keefe JH (2007) White cell count, mortality, and metabolic syndrome in the Baltimore longitudinal study of aging. J Am Coll Cardiol 50:1810-1811

3. Bottini PV, Ribeiro Alves MA et al (2002) Electrophoretic pattern of concentrated urine: comparison between 24-hour collection and random samples. Am J Kidney Dis 39:E2

4. Coombes KR, Morris JS et al (2005) Serum proteomics profiling-a young technology begins to mature. Nat Biotechnol 23:291-292

5. De Angulo G, Yuen C et al (2008) Absolute lymphocyte count is a novel prognostic indicator in ALL and AML: implications for risk stratification and future studies. Cancer 112:407-415

6. de Roos B, Duthie SJ et al (2008) Proteomic methodological recommendations for studies involving human plasma, platelets, and peripheral blood mononuclear cells. J Proteome Res 7:2280 2290

7. de Roos B, Geelen A et al (2008) Identification of potential serum biomarkers of inflammation and lipid modulation that are altered by fish oil supplementation in healthy volunteers. Proteomics 8:1965-1974

8. de Roos B, McArdle HJ (2008) Proteomics as a tool for the modelling of biological processes and biomarker development in nutrition research. Br J Nutr 99:S66-S71

9. Echan LA, Tang HY et al (2005) Depletion of multiple highabundance proteins improves protein profiling capacities of human serum and plasma. Proteomics 5:3292-3303

10. Fang X, Zhang WW (2008) Affinity separation and enrichment methods in proteomic analysis. J Proteomics 71:284-303

11. Fuchs D, Piller R et al (2007) The human peripheral blood mononuclear cell proteome responds to a dietary flaxseed-intervention and proteins identified suggest a protective effect in atherosclerosis. Proteomics 7:3278-3288

12. Fuchs D, Vafeiadou K et al (2007) Proteomic biomarkers of peripheral blood mononuclear cells obtained from postmenopausal women undergoing an intervention with soy isoflavones. Am J Clin Nutr 86:1369-1375

13. Fuchs D, Winkelmann I et al (2005) Proteomics in nutrition research: principles, technologies and applications. Br J Nutr 94:302-314

14. Garcia A, Watson SP et al (2005) Applying proteomics technology to platelet research. Mass Spectrom Rev 24:918-930

15. Gnatenko DV, Perrotta PL et al (2006) Proteomic approaches to dissect platelet function: half the story. Blood 108:3983-3991

16. Gross JL, de Azevedo MJ et al (2005) Diabetic nephropathy: diagnosis, prevention, and treatment. Diabetes Care 28:164-176

17. Helmerhorst EJ, Oppenheim FG (2007) Saliva: a dynamic proteome. J Dent Res 86:680-693

18. Hu S, Loo JA et al (2006) Human body fluid proteome analysis. Proteomics 6:6326-6353

19. Hu S, Xie Y et al (2005) Large-scale identification of proteins in human salivary proteome by liquid chromatography/mass 
spectrometry and two-dimensional gel electrophoresis-mass spectrometry. Proteomics 5:1714-1728

20. Huang L, Harvie G et al (2005) Immunoaffinity separation of plasma proteins by IgY microbeads: meeting the needs of proteomic sample preparation and analysis. Proteomics 5:3314-3328

21. Kim H, Page GP et al (2004) Proteomics and mass spectrometry in nutrition research. Nutrition 20:155-165

22. Kuss I, Hathaway B et al (2004) Decreased absolute counts of T lymphocyte subsets and their relation to disease in squamous cell carcinoma of the head and neck. Clin Cancer Res 10:3755-3762

23. Kussmann M, Affolter M (2006) Proteomic methods in nutrition. Curr Opin Clin Nutr Metab Care 9:575-583

24. Kussmann M, Raymond F et al (2006) OMICS-driven biomarker discovery in nutrition and health. J.Biotechnol. 124:758-787

25. Lau B, Gange SJ et al (2003) Rapid declines in total lymphocyte counts and hemoglobin concentration prior to AIDS among HIV1-infected men. AIDS 17:2035-2044

26. Michelson AD (2007) The clinical approach to disorders of platelet number and function. 2:825-830

27. Milner JA (2007) Nutrition in the 'omics' era. Forum Nutr 60:1-24

28. O'Neill EE, Brock CJ et al (2002) Towards complete analysis of the platelet proteome. Proteomics 2:288-305

29. Omenn GS, States DJ et al (2005) Overview of the HUPO Plasma Proteome Project: results from the pilot phase with 35 collaborating laboratories and multiple analytical groups, generating a core dataset of 3020 proteins and a publicly-available database. Proteomics. 5:3226-3245
30. Pisitkun T, Johnstone R et al (2006) Discovery of urinary biomarkers. Mol Cell Proteomics 5:1760-1771

31. Rai AJ, Gelfand CA et al (2005) HUPO Plasma proteome project specimen collection and handling: towards the standardization of parameters for plasma proteome samples. Proteomics 5:32623277

32. Ruggiero C, Metter EJ et al (2007) White blood cell count and mortality in the Baltimore longitudinal study of aging. J Am Coll Cardiol 49:1841-1850

33. Thongboonkerd V (2007) Practical points in urinary proteomics. J Proteome Res 6:3881-3890

34. Thongboonkerd V (2007) Recent progress in urinary proteomics. Proteomics Clin Appl 1:780-791

35. Thongboonkerd V, Chutipongtanate S et al (2006) Systematic evaluation of sample preparation methods for gel-based human urinary proteomics: quantity, quality, and variability. J Proteome Res 5:183-191

36. Yamamoto T, Langham RG et al (2008) Towards standard protocols and guidelines for urine proteomics: a report on the Human Kidney and Urine Proteome Project (HKUPP) symposium and workshop, 6 October 2007, Seoul, Korea and 1 November 2007 , San Francisco, CA, USA. Proteomics 8:2156-2159

37. Yu HH, Wang LC et al (2007) Lymphopenia is associated with neuropsychiatric manifestations and disease activity in paediatric systemic lupus erythematosus patients. Rheumatology (Oxford) 46:1492-1494 